\title{
Akadályok a nők karrierjének útjában - a szervezetek útvesztői
}

\author{
TAKÁCS IZOLDA ${ }^{1}$
}

\begin{abstract}
ABSZTRAKT
A munkavállaló nök végzettségük, képességeik ellenére is számtalan akadályba ütköznek karrierjük során. Bár tényként megállapítható, hogy az elmúlt évtizedekben jelentősen megnôtt a női vezetők aránya, ez a változás kevéssé érte el a felső szintű vezetői pozíciókat, ahol továbbra is alulreprezentáltak. Számos elemzés megállapította, hogy ennek az egyenlőtlen helyzetnek, illetve a munkahelyi szegregációnak okai alapvetően a társadalmi kódokban, a férfi-nő hierarchia több évszázados jelenlétében keresendők.

Jelen tanulmány megpróbálja azonosítani, hogy pontosan milyen nehézségekkel, akadályokkal találják szembe magukat a nők, amint feljebb kerülnek a foglalkoztatási hierarchiában. Mindeközben sorra veszi a munkahelyi szervezetek általános jellemzőit, azok légkörét stb., továbbá a vezető nőkkel párosított, bináris oppozíciókon alapuló elöítéleteket, melyek miatt végül hármas teher került a diplomás nókre.
\end{abstract}

KULCSSZAVAK: nők, üvegplafon, munkaerőpiac, szervezet, diszkrimináció

\section{ABSTRACT}

\section{Obstacles for women in career advancement}

Today the level of knowledge, qualifications of female are immensely increasing, but despite their skills there are still encounter obstacles in their careers, and women still appear to be underrepresented in top-level leadership positions. Many analysis findings indicated that there is a strong negativ relationship bertween the impact of the old traditions and women career developement.

This paper attempts to identify all the obstacles and gender-related segregation of the labour market such as vertical and horizontal segregations and also raises awareness of that complex problem. Because there is a triple burden on graduate and leading women, work at home, their job and the struggle with the sexist working environment.

KEYWORDS: women, glass ceiling, labor marke, organization, discrination

\footnotetext{
${ }^{1}$ Szociológus, társadalomkutató PhD, izolda.t@hotmail.com.
} 


\section{TEMATIKUS TANULMÁNYOK - Emberierőforrás-menedzsment napjainkban}

\section{Bevezetés}

Még ma is sok az olyan munkavállaló nő, aki végzettsége, képessége ellenére is akadályokba ütközik karrierje során. Bár tényként megállapítható, hogy az elmúlt évtizedekben jelentősen nőtt a női vezetők aránya a fejlett országokban, de ez a változás alig érte el a felső szintű vezetői pozíciókat, ahol a nők továbbra is alulreprezentáltak (Monori 2011). Magyarország a változások ellenére is csak a 103. helyet foglalta el a Global Gender Gap Index 2017-es rangsorában, amely 144 országot vizsgált, majd hasonlított össze, többek között annak alapján, hogy mekkora nemi egyenlőtlenségek mutathatók ki a gazdasági részvétel és lehetőségek területén. Ez az arány 2018ra alig változott, akkor 149 ország közül a 102. helyen szerepelt hazánk. ${ }^{2}$

Nyugat-Európában és Észak-Amerikában az 1950-es években kezdődött el a nők nagyobb arányú beáramlása a munkaerőpiacra. Ekkor jelent meg a kutatásokban is a munkaerőpiac szegregálódása mint témakör, majd az 1970-es évektől egyre több vizsgálat foglalkozott vele. Már akkor is kiviláglott, hogy a nők és a férfiak munkahelyi státusza és lehetőségei a magasabb pozíciók elérésére teljesen különbözőek egymástól (Nagy - Primecz 2010). Joan Acker pedig kimutatta, hogy a munkahelyi szervezeteket nemcsak, hogy átszövi a nemek kérdésköre, „de egy nemileg átitatott mélyszerkezet (gendered substructure) alapozza meg" (Acker 1998 idézi Nagy 2017: 59).

Az 1990-es évektől zajló kutatások egyik megválaszolandó kérdése éppen az volt, és amire a jelen írás is választ keres, hogy vajon miért ilyen lassú a változás a nők arányát illetően, és miért csak jelképes a nők szerepe a felső szintű vezetésben, annak ellenére, hogy ugyanazzal a képzettségi szinttel és képességekkel rendelkeznek, mint férfi kollégáik (lásd még Nagy - Primecz 2010). Sőt, mára a felsőoktatásban végzett nők aránya magasabb, mint a férfiaké. (Az egyetemet végzett nők aránya nagyjából 53\%, míg a férfiaké $47 \%$. ${ }^{3}$

\section{A nemi alapú szegregáció}

Az egyenlőtlen helyzet egyértelműen a nemi alapú szegregációra vezethető vissza. A nők a munkaerőpiacon ugyanis mind a vertikális, mind pedig a horizontális szeg-

2 The Global Gender Gap Report 2018, 11. oldal, Table 3: Global rankings, 2018 (cont'd.) http:// www3.weforum.org/docs/WEF_GGGR_2018.pdf letöltés ideje: 2018. 12. 01. 2017-ben 144 ország között a 104. helyen állt Magyarország, vö.: http://www3.weforum.org/docs/WEF_GGGR_2017.pdf, 11. oldal 2017 (cont'd)

${ }^{3}$ Arányszámokat lásd, Nők és férfiak aránya a tudományos pálya egyes állomásain Magyarországon (2014) táblázat, forrás: https://mta.hu/mta_hirei/attorni-az-uvegplafont-kijutni-az-utvesztobol-elsokentult-ossze-a-nok-a-tudomanyban-kerekasztal-az-akademian-107103 


\section{TEMATIKUS TANULMÁNYOK - Emberierőforrás-menedzsment napjainkban}

regációval találkoznak. ${ }^{4} \mathrm{~A}$ horizontális szegregáció alatt a férfiak és a nők különböző gazdasági területen, szektorokban, foglalkozásokban való elhelyezkedését értjük, amit az üvegfal metaforával jelölnek. A vertikális szegregáció pedig, melyet az üvegplafon kifejezés helyettesít, a foglalkozási hierarchián való előrejutási akadályokat foglalja magában. Ez utóbbi jelenségnek a következménye, hogy a nők azonos szakmai felkészültség esetén is lényegesen kisebb eséllyel futnak be munkahelyi karriert, mint a férfiak (Hymowitz - Schellhardt 1986). Az üvegplafon kifejezés először 1986-ban jelent meg a szakirodalomban. Carol Hymowitz és Timothy D. Schellhardt a The Glass-Ceiling: Why Women Can't Seem to Break the Invisible Barrier that Blocks Them from Top Jobs ${ }^{5}$ címú jelentésben foglalták össze, milyen kihívásokkal szembesülnek a nők az üzleti világban. ${ }^{6}$

Koncz Katalin a fent nevezett üvegplafon-jelenséget „szerkezeti holtpontnak” definiálta, mely tulajdonképpen az előmenetel végét jelenti egy szervezetben, és akkor áll elő, ha az adott intézmény nem tud előmeneteli lehetőséget biztosítani valamely strukturális ok miatt (Koncz 2011, Koncz 2016a).

A munkahelyi szegregációnak okai alapvetően a társadalmi kódokban, a férfi-nő hierarchia több évszázados jelenlétében keresendők. Ismeretes, hogy ezeknek megváltoztatására, vagyis a nőkkel kapcsolatos elóítéletek „orvoslására” számos társadalmi igyekezet, többféle feminista irányzat és kezdeményezés született. Ezek egymással hasonló és/vagy különböző módon, abban a célban egyesültek, hogy ne legyen kérdés a biológiai nem a társadalmi szerepeket illetően. Vagyis mindkét nem kivehesse részét a neki tetsző, vagy kívánatos szakmákból és szerepekből. Az ezekre való alkalmasság kulcsa ugyanis az egyénben van, és nem a biológiai nem által determinált szerepekre szúkül. Azonban a szokások, a hagyományos nemi előítéletek mélyen beépültek a társadalmi térbe, a diskurzusokba, és közvetlen vagy közvetett módon határozzák meg még ma is a nők helyét a társadalomban betöltött szerepüket illetően. Ez a munkaerőpiacon a női vezetőkről alkotott mítoszokban manifesztálódik.

Az ilyen nemi alapú differenciálódás pszichológiai magyarázata tehát elsősorban ezeknek a feltételezéseknek az észlelt összeférhetetlenségén alapul. Vagyis azon, hogy mit is jelent jó vezetőnek lenni, és hogy mit jelent nőnek lenni, és amelyeket

\footnotetext{
${ }^{4}$ Nemzetközi összehasonlító elemzések bizonyítják, hogy a munkaerőpiac nemek szerinti szegregációja a világ minden országában jelen van és stabilan tartja magát (Anker [1998], Charles [1992]), annak ellenére, hogy a nők és a férfiak eltérő munkaerőpiaci jellemzői és iskolázottsága tekintetében közeledés tapasztalható" (Koncz 2010: 1083).

${ }^{5}$ Wall Street Journal.

${ }^{6}$ Bár „az üvegplafon metafora eredete az 1980-as évekre vezethető vissza, de korábbi kutatások, pl. Rosabeth Moss Kanter Men and Women of the Corporation című műve már az 1970 -es években bemutatták, hogy mennyire különböző pozícióban vannak, és mennyire mást tehetnek a nők és a fériak a szervezetekben" (Kanter 1977 idézi Nagy 2017: 60).
} 


\section{TEMATIKUS TANULMÁNYOK - Emberierőforrás-menedzsment napjainkban}

egymással ellentétesnek definiáltak. Ez utóbbi pedig a „think manager-think male” (TMTM) metafora néven vált ismertté (Ryan S. - Haslam - Hersby 2011). ${ }^{7}$

Miután a férfiakhoz párosított attitűdök nagyobb átfedésben vannak a vezetőről alkotott képpel, emiatt ezekre a posztokra leginkább a férfiakat tartják alkalmasnak. Ebből kifolyólag eleve sokkal nehezebb bekerülni a nőknek a magasabb politikai, gazdasági hatalommal felruházott területekre, vezető pozíciókba (Vida - Kovács 2017: 145).

Ilyen és ehhez hasonló társadalmi értékítélettel kapcsolódik össze a munkaerőpiac nemek szerinti szegregációja, és ebből kifolyólag jelent társadalmi problémát. Hiszen emiatt „nem tud megvalósulni sem a meritokrácia elve (ha a nemek hasonlóságát hangsúlyozzuk), sem pedig a nők speciális hozzájárulása és értéke (ha a két nem különbözőségét tartjuk szem előtt)" (Nagy - Primecz 2010: 14).

A témához a már említett horizontális szegregáció, a nőies szakma versus férfias foglalkozások korban változó, de éles elkülönítése is hozzátartozik. Ismeretes, hogy a nők általában a szociális szférában felülreprezentáltak, ugyanakkor még ma is kevesen vannak a múszaki és a természettudományokban.

Koncz Katalin szerint azonban a szakmák nemek szerinti elkülönítése nem természetellenes, mert a nők és férfiak biológiai és társadalmi okokból eltérő kompetenciái, lehetőségei mások. Vagyis arra utal, hogy alapvetően nem a szegregáció az, amely az egyenlőtlenségeket okozza (Koncz 2011, lásd még Koncz 2016b). Ugyanakkor itt megemlítem Phillips azon állítását, miszerint lehetséges, hogy „a nők-férfiak különbözőségéről szóló esszencialista érvelés mégis paradox módon fenntartja azt a hierarchiát, amit lebontani igyekszik. Megerösíti ugyanis a csoportok közötti kategóriahatárokat és azt a feltételezést, hogy a csoportok tagjai - az értékelés elójelétól függetlenül - lényegileg mások" (Phillips 2010 idézi Kovács - Szabó 2017: 44).

Mindenesetre a probléma Koncz szerint inkább azokkal a munkaerőpiaci mechanizmusokkal $^{8}$ van, amelyek ezeket a természetes különbségeket és az ezekből adódó foglalkozási struktúrában való elhelyezkedést társadalmi hátránnyá formálják (Koncz 2011).

7 Ezenfelül gondoljunk csak arra, hogy például a gondoskodás - melyet biológiai alapon a női természet részének tekint a társadalom - egyáltalán nem váltható társadalmi státuszra. De a nők gondoskodására - lehetőleg ellenszolgáltatás nélkül - szüksége van a domináns csoportnak, így ez részévé vált a női szerep „előírásainak” (lásd Glick - Fiske 2006 idézi Vida - Kovács 2017: 143).

${ }^{8}$ Ezt igazolják a legújabb észak-amerikai kutatások is. Ezek azt mutatják, hogy az aktív, intenzív apaszerepet betöltő férfiak ugyanolyan mértékű munka-magánélet közötti konfliktusról számolnak be, mint a munkaerőpiacon aktív anyák (Williams et al. 2013). Williams és szerzôtársai nem a szervezeti struktúra, hanem a szervezeti elkötelezettség irányából közelítettek ahhoz a kérdéshez, hogy miért nem kérdőjeleződnek meg a szervezeti gyakorlatok. Az észak-amerikai kutatások összegző áttekintésükben bemutatják, hogy a munka iránti elkötelezettség morális elvárása ütközik azzal az általános igénnyel, hogy a munkavállaló rugalmasan dolgozhasson, még akkor is, ha az osztályjellemzőket figyelembe veszik (Williams et al. 2013 idézi Nagy 2017: 65). 


\section{TEMATIKUS TANULMÁNYOK - Emberierőforrás-menedzsment napjainkban}

Miközben ennek legfőképpen azért van jelentősége, mert azok a foglalkozások, melyeket férfiak töltenek be magasabb presztízzsel járnak, emellett szignifikáns keresetbeli különbségben is megmutatkoznak a nőies és a férfias szakmák között (gender pay gap). Ezt a kérdéskört csak annyiban érinti, hogy a vezető pozíciókban mindenképpen kevés a nő, legyen szó nőies, avagy férfias foglalkozásról, szektorról. Ezt leginkább az bizonyítja, hogy még egy nők által felülreprezentált szakmában, szervezetben is férfi a vezető. Erre a jelenségre a szakirodalom az úgynevezett üveglift (glass elevator/escalator) kifejezést hozta szemben az üvegplafonnal, amit a férfiak által uralt foglalkozásokban a nők tapasztaltak.

A férfiak, akik női vagy nők által dominált szakmában dolgoznak, érzik ezt a bizonyos üveglift-hatást. Ez az, ami megkönnyíti nekik a gyors felfelé történő mobilitást a ranglétrán még ezeken a területeken is (Wingfield 2009). Az üveglift egy mindmáig működő jelenség, mely segít a nők munkáját végző férfiak tapasztalatainak megértésében is.

A fogalmat Christine Williams amerikai szociológus alkotta meg 1992-ben, amikor a férfi ápolók, a szociális munkások, a könyvtárosok körében végzett kutatásában a férfiak következetes előnyét mutatta ki. Megállapításai szerint, még az olyan munkakörökben is, ahol a férfiak jelentős számú kisebbségben vannak, valószínűleg magasabb béreket kapnak és gyorsabban lépnek előbbre a ranglétrán, mint a női munkatársak (Wingfield 2009: 6).

Williams később, az általa évtizedekkel korábban bevezetett koncepciót az eredeti elemzésére alapozva építette tovább (Williams 2013), többek között azokra a hiányosságokra utalva, melyeket a metafora nem tudott megfelelően összefoglalni. A koncepciónak szerinte két fő korlátja volt. Először is az, hogy nem sikerült megfelelően megbirkóznia az interszekcionalitással, hiszen a rassz, a szexuális orientáció és az osztály metszetét nem vette figyelembe, és csak a hetero, fehér, középosztálybeli férfiak tapasztalatain alapult a vizsgálata. Egyértelmű ugyanis, hogy pl. a fekete és a meleg férfiak nem feltétlenül élvezik az üveglift pozitív hatásait. Tovább árnyalja a jelenséget Williams, amikor megemlíti Adrienne Rich „fehér szolipszizmusnak” nevezett fogalmát, miszerint a „fehér” tapasztalat az összes többi csoport normája, átlaga és modellje. Vagyis mindazok, akik ettől a „fehér” normától eltérnek, azok „kivételeknek" tekintendők. A másik probléma az üveglift fogalommal az volt, hogy a fenomén a tradicionális munkaszervezetek szerkezetén alapult, amelyek mára jelentősen átalakultak. Az üveglift jelensége többek közt stabil foglalkoztatást feltételezett, bürokratikus hierarchiát, mint amelyek az állami támogatású közintézményeknél figyelhetőek meg (például oktatási intézmények, könyvtárak stb. esetében). Ugyanakkor ezek az erősen tagolt szervezetek ma már nem jellemzik a munkaerőpiacot, mára a munkahelyek rugalmasabbá váltak, projektalapúak és átmenetiek lettek (Williams 2013). 


\section{TEMATIKUS TANULMÁNYOK - Emberierőforrás-menedzsment napjainkban}

A témában kutató szakemberek rámutattak arra, hogy a posztmodern szervezetek a társadalom megváltozott lehetőségeire reagálva, szemben a régi fordista modellek vertikálisan tagolt, erősen hierarchizált munkaszervezésével, ma már a flexibilitásra helyezik a hangsúlyt és inkább csak a főtevékenységekre fókuszálnak, minden egyéb tevékenységet külső szolgáltatókra bíznak. Ezek eredményeképpen a modern szervezetek lényegesen kevesebb szervezeti szinttel rendelkeznek, sokkal „laposabbak”, ezáltal kevésbé hierarchikusak, mint a régi „fordista piramisok”. Emellett lehetőséget biztosítanak az atipikus munkaviszonyok létesítésére is (Kürtösi 2008). Ezeken a területeken tehát külön kell kezelni a szervezeti ranglétrát azoktól a területektől, ahol még a tradicionális mintát követik a hierarchiában való feljebbjutást illetően.

A XXI. században tehát új fogalmakra van szükség a munkahelyi nemi egyenlőtlenség megértéséhez, annak ellenére is, hogy a szociális munkás, a könyvtáros munkakörökben máig változatlanul jellemzőek a régi minták (Williams 2013).

Ahogy az eddigiekből is kiderült, karrierjük során a nők előtt a problémák kimérája magasodik, amelyet minden oldalról patriarcha tradíciók táplálnak tovább. Jelen írás a következőkben sorra veszi a munkahelyi szervezetek általános jellemzőit, azok légkörét stb., továbbá a vezető nőkkel párosított, bináris oppozíciókon alapuló előítéleteket, melyek még ma is határok közé szorítják őket. Illetve konkrétan felsorolja milyen nehézségekkel, akadályokkal találják szembe magukat a nők, amint feljebb kerülnek a foglalkoztatási hierarchiában.

\section{Akadályok a munkahelyi szervezetekben}

Kiindulópontom tehát, hogy az azóta eltelt időben (az 1950-es évektől), a szervezetek modernizációjával sem oldódott meg a nők karrierje során tapasztalt problémakör. Sőt nem is csupán az említett egy-két akadályról beszélhetünk, hanem egy rendkívül komplex, többszörösen összetett jelenséggel állunk szemben. Igaz, hogy a nők ma már felülreprezentáltak az egyes szakmában (még a korábban férfias szakmákban is, pl. jogász, orvos), és ahogy a bevezetőben is említettem, a nyugati államokban jelentősen megemelkedett a női vezetők aránya is. Ugyanakkor ezek a számok elrejtik azokat a jelenségeket, melyek máig megnehezítik a nők számára a bekerülést a felső vezető szintekre, döntéshozó munkakörökbe.

Akármilyen szervezetről is beszélünk, mindegyiken belül ,jelen vannak azok a hétköznapi szokások és folyamatok, amelyek reprodukálják az egyenlőtlenségeket, megerősítik és természetesnek tüntetik fel az egymásra rétegződő egyenlőtlenségeket. [...] A folyamat eredménye pedig a helyzet megkérdőjelezhetetlensége" (Nagy 2017: 59).

Ezeknek a folyamatoknak, jelenségeknek a felsorolása, körülírása segíthet megoldásokat eszközölni. A már említett „üvegplafon”, „üvegfal”, „üveglift” mellé további 


\section{TEMATIKUS TANULMÁNYOK - Emberierőforrás-menedzsment napjainkban}

metaforák születtek, hogy tovább árnyalják ezt az összetett jelenséget, és minél pontosabban felmérjék a problémák számát és nagyságát ezen a területen. Így a fent leírt fogalmak mellett megjelentek olyan szimbólumok is, mint az „üvegszikla”, „labirintus”, ,kritikus tömeg”, „Matilda-hatás” stb. Bár ezek mindegyikére nem térek ki, de az akadályok felsorolása magában foglalja a meglévő metaforák tartalmát is.

Összefoglalva mindezeket, a jelzők mögött rejlő gátak, még ma is (1) vagy rendkívül nagy nehézséget okoznak a nőknek az előrelépésben, (2) vagy pedig végleg megállítják őket a munka és a tudomány világában történő önkiteljesedésükben és a lemorzsolódásukhoz vezet.

\section{1. ÖNDISZKRIMINÁCIÓ ÉS LABIRINTUS}

A vertikális szegregácó okozza például azt is, hogy a nők maguk sem választanak bizonyos foglalkozásokat, munkákat, tudományterületet, holott megtehetnék, vagyis „öndiszkrimináció” áldozatai lehetnek (Nagy - Primecz 2011: 8). Így az üvegplafon-jelenség nem feltétlenül egy külső, objektív akadály meglétét jelenti csupán, hanem belsővé tett, emiatt a szabad választás látszatát is keltheti. Ez tovább igazolja a fent tett megállapításomat, miszerint a szegregációs tényezők rendkívül szoros, kölcsönös összefüggésben vannak egymással, és ezek miatt a nők pályafutásuk során valahol elakadnak vagy lemorzsolódnak (Nagy - Primecz 2011).

Így pl. sokkal adekvátabb kifejezés a problematikára az úgynevezett labirintus. E kortárs metafora jeleníti meg azt a konfliktusokkal teli nehéz utat, ami a nőkre vár a munkahelyi előrelépést, a karriert illetően. A labirintuson való áthaladás megköveteli a kitartást, a tudatos előrehaladást, és a szembe jövő nehézségek gondos felmérését és elemzését. De, miután minden labirintusban van egy lehetséges, járható út a cél felé, így végül is az objektíve elérhető. Carli és Eagly szerint, ha felmérjük, majd pontosan megnevezzük a labirintust alkotó különböző akadályokat, valamint azt, hogy egyes nők hogyan rekednek meg ezen gátló tényezők közt, úgy hatékonyabban tudunk dolgozni a helyzet javítása érdekében is (Carli - Eagly 2007).

Carli és Eagly négy jól körülhatárolható akadályt nevezett meg, (I) az előítéletekből fakadó hátrányokat, (II) a női vezetés elutasítását, a vezetői stílus problematikáját, (III) a családi élet és a karrier összeegyeztetésének nehézségeit és (IV) a kevés társadalmitőke-befektetést (Carli - Eagly 2007).

Nagy Beáta ezeket a gátakat további kategóriákra bontotta, (1) előítéletekre, (2) a nők kompetenciájának megkérdőjelezésére, (3) a nem támogató vezetői stílusra, (4) a munka és a magánélet összehangolásának nehézségeire, (5) kapcsolati tőke hiányára, (6) arra, hogy pl. a tudományos életpálya a férfiakra szabott, (7) a „Máté-hatás"-ra és (8) a Matilda-hatásra, (9) arra, hogy a férfiak önértékelése általában magasabb, a nőké alacsonyabb a valós teljesítményüknél, (10) a média szerepére, 


\section{TEMATIKUS TANULMÁNYOK - Emberierőforrás-menedzsment napjainkban}

(11) a „hűvös klímára”, (12) a „jóindulatú szexizmus”-ra (Nagy é. n.). ${ }^{9}$ Ezeket alább részletezem, bár eltekintek a sorrendtől. Az akadályokat inkább aszerint csoportosítottam, hogy melyek azok az akadályok, amelyek jellemzően még az üvegplafon áttörése előtt lépnek elő, és melyek azok, amelyek a már vezetői státuszban lévő nőket fenyegetik.

\section{A nők előtt álló akadályok az „üvegplafon” előtt}

Az előítéletek, sztereotípiák, vagyis az a tény, hogy a férfiak és a nők különböző módon viselkednek, beszélnek stb. - és emiatt más-más szerepet kell betölteniük a társadalomban - az egyik sarokköve a nemekkel kapcsolatos mítoszoknak. Ezek leginkább a munkaerőpiacon érhetők tetten és már a diploma megszerzése után, az első fizetésekben megmutatkoznak (gender pay gap). Ezzel szorosan összefügg a nők kompetenciájának megkérdőjelezése is bizonyos (presztízzsel, jó fizetéssel járó) szakmákban (vö. Nagy 2016). Ennek egyik látványos formája már a munkainterjú során megmutatkozik. Csakhogy „a nők (és a férfiak) munkaköri interjúkban tanúsított viselkedéséről és nyelvhasználatáról nagyon kevés tanulmány íródott annak ellenére is, hogy az állásinterjú az első jelentős lépés a karrierépítésben" (Thoralf 2005: n. a. ${ }^{10}$. Éppen ezért rendkívül érdekes pl. Daniela Wawra Männer und Frauen im Job Interview című könyve, melyben arról írt, hogy a férfiak és a nők nyelvhasználatukban jelentősen különböznek egymástól. Ezeket az eltéréseket pedig interdiszciplinárisan, a nyelvészet, a társadalomtudományok, a genetika és az evolúciós pszichológia, valamint a közgazdaságtan szemszögéből is leírta és magyarázta (az angol nyelvet és kultúrát vizsgálva). Szerinte a két nem alapvetően eltérő kommunikációja az oka a diszkriminációnak, amely a munkainterjúk során rendre előkerül. Ezen megállapítása tulajdonképpen visszautal a már említett „fehér szolipszizmus” jelenségére is, mely az alapvető normákat a fehér férfiak normájában méri, és ami ettől eltér, gyengeségként értelmezi. Wawra szerint alapvetően ezekre az eltérésekre kell elsősorban felhívni a figyelmet, és ezekkel operálva kell az adott munkafelvételi beszélgetést is értékelni, hogy biztosan a szakmailag legmegfelelőbbek kerüljenek az adott posztra (Thoralf 2005). Ez pedig tovább igazolja azt a felvetést, miszerint a képzettség és a teljesítmény a nemiség után jön csak számításba (még akkor is, ha közvetett módon van csak jelen a sztereotípia). Nagy Beáta kutatásai szintén alátá-

${ }^{9}$ Lásd még: Áttörni az üvegplafont, kijutni az útvesztőből - Nők a tudományban kerekasztal az Akadémián http://mta.hu/mta_hirei/attorni-az-uvegplafont-kijutni-az-utvesztobol-elsokent-ult-ossze-a-noka-tudomanyban kerekasztal-az-akademian-107103 (utolsó letöltés 2018. 04. 30.)

${ }^{10}$ Saját fordítás, Thoralf (2005): Frauen und Männer verhalten sich im Bewerbungsgespräch unterschiedlich, http://www.uni-passau.de/bereiche/presse/pressemeldungen/meldung/detail/frauen-und-maenner-verhalten-sich-im-bewerbungsgespraech-unterschiedlich/ (utolsó letöltés: 2018. 05. 01.) 


\section{TEMATIKUS TANULMÁNYOK - Emberierőforrás-menedzsment napjainkban}

masztják a szociálpszichológiai vizsgálatok azon eredményeit, mely szerint nem anynyira az egyéni képességeken, mint inkább a társadalmi feltételeken múlik, hogy nincsenek nagyobb arányban nők a vezetők között (Nagy 2005).

A teljesítménynek tehát gyakran eltérő a megítélése a két nemnél. Ezt az állítást tovább igazolja az úgynevezett Goldberg paradigma is, melyet Philip Goldberg 1968-as kísérlete után neveztek el. Ennek során diákok két csoportjának azonos eszszéket kellett értékelniük, az egyetlen különbség az volt, hogy egyszer férfit, utána nőt neveztek meg szerzőnek. Az eredmény kimutatta, hogy a hagyományos női témákat kivéve rosszabbul értékelték a női névvel ellátott szövegeket (ami ugyanaz volt), mint a férfi nevével aláírtakat (Riedel - Schiessel 2011). Az eredmények tehát alapvetően azt mutatják, hogy a nőknek tulajdonított munkákat negatívabban értékeli mind a két nem, mint a férfiakét (Burgess - Borgida 1999).

Ugyanakkor azt sem szabad elfelejtenünk, hogy a társadalmi kontextusban nemcsak a nemiség jelenti az értékelés egyetlen fő komponensét, hanem több tényező együttes kölcsönhatása alakítja ki az elóítéleteket. Így pl. a fizikai kompetencia, a beszédkommunikáció, a nonverbális kommunikáció és egyéb sztereotípiák (Burgess - Borgida 1999). De sok esetben mégis a nemiség adja a megkülönböztetés legfóbb alapját.

A nők számára a labirintus legvégzetesebb akadálya viszont kétségkívül a munka és a magánélet összehangolásának nehézsége, mely mindig kettős terhet jelent a nőknek. Ez alapvetően a családi felelősség nyomásán alapul, konkrétan azon, hogy továbbra is a nők azok, akik megszakítják a karrierjüket, vagy csak részmunkaidőben dolgoznak gyermekvállalás esetén. Ennek eredményeként kevesebb munkatapasztalatuk lesz, ami lényegesen lelassítja karrierjüket és csökkenti bevételi forrásukat is (Carli - Eagly 2007). Ezt a jelenséget hívhatjuk az úgynevezett anyasági hátránynak.

$\mathrm{Az}$ „,anyasági hátrány” fogalma olyan egyenlőtlenségre utal, akár a nők csoportján belül is, amely azokat érinti csak, akiknek gyermekgondozási feladataik vannak és emiatt kerülnek jelentős hátrányba, kevesebb bért kapnak, vagy könnyebben megszüntetik a munkaviszonyaikat (Koplányi 2018: 304).

Erre már több államban léteznek megoldások, „pl. a Billing által vizsgált északi országokban a gender rezsim része az is, hogy a szülő́k közösen viselnek felelősséget a gyermekgondozásért, így egyik szülő sem tekinthető teljesen tehermentesnek (Billing 2011 idézi Nagy 2017: 65). Láthatjuk ugyanezt egyes nyugati országok (Franciaország) példáján keresztül is, ahol az apák bevonása a korai gyermekgondozásba nemcsak elősegítette a nők tehermentesítését, de egy pozitív társadalmi klíma kialakulásához is vezetett (Pongrácz - S. Molnár 2011).

Ugyanakkor az egyes vizsgálatokból az is kiderült, hogy sok helyen, pl. az Egyesült Államokban (de hazánkra is igaz) még azok a nők is, akik megosztották a gyer- 


\section{TEMATIKUS TANULMÁNYOK - Emberierőforrás-menedzsment napjainkban}

meknevelést a férjeikkel, ${ }^{11}$ vagy más családtagokkal, annak ellenére sem élvezhették a munkahelyi előnyöket, lehetőségeket. A munkáltatók ugyanis gyakran azt feltételezték, hogy az anyák háztartási/otthoni felelősségük miatt eleve alkalmatlanok az embert próbáló, egész embert igénylő pozíciókra. „Volt a választható listán 2 vagy 3 női név - mondta el az egyik dolgozó a Carli és Eagly által végzett kutatásban -, akikre azt mondták, hogy eleve nem is jöhetnek számításba, mert gyermekeik vannak, akik otthon várják óket ebben a [esti] órában." (Carli - Eagly 2007: n. a.) Érdekes módon ugyanezt nem említették meg a férfiakkal kapcsolatban, holott közülük sokaknak szintén voltak gyermekeik (Carli - Eagly 2007). „Vagyis a gyermekvállalás, mint specifikus női "probléma abból ered, hogy kultúránk hajlamos adottnak venni az anya elsődleges gondozói szerepét" (Séllei 2015: 270).

Magyarországon a férfiak és nők együttélését döntően még mindig a hagyományos szerepmegosztás jellemzi, ugyanis a magyar társadalomban nem szünt meg a háztartás és gyermeknevelés nagyobbrészt nőkre háruló terhe. Az elmúlt évtizedekben folytatott attitűdkutatások (Blaskó 2005, Pongrácz 2001 idézi Neményi 2016: 246) azt is alátámasztották, hogy a családdal és családi szerepekkel kapcsolatos felfogás alig változóan, döntően a hagyományos minták szerint alakult, és még mindig a férfiakat tekintik családfőnek (Neményi 2015).

Ezzel szorosan összefügg egy másik probléma is. Egyes szervezetszociológiai vizsgálatok szerint a nők nem teljesértékủ munkavállalók, hanem olyanok, akik támogatásokra szorulnak a munkahely részéről, és ezzel azt a képet erősítik, hogy a kisgyerekes nők állandó szervezeti segítség mellett tudják csak feladataikat elvégezni (Nagy 2017).

A fentiek értelmében tehát az ideális munkavállaló mindenképpen egy tehermentes (unemcumbered) munkavállaló. A szakirodalom (Acker 1998) ezt még testetlen (disembodied) munkavállalónak is nevezi, akinek alakja természetesen a férfi munkavállalóhoz áll közel. Éppen ezért kiszorulnak pl. azok, akiknek bármilyen nevelési, gondozási feladataik vannak, és akik túlnyomó többségben nők. A modell értelmében tehát a foglalkoztatás férfinorma, hiszen alapvetően egy férfiakra szabott elvárásrendszert tesz általánossá (Acker 1998 idézi Nagy 2017). Acker szerint „az univerzális munkavállaló elképzelése kizárja és marginalizálja a nőket, akik szinte definíciószerüen nem tudják elérni a valódi dolgozó kvalitásait, mivel ez azt jelentené,

${ }^{11}$ Itt meg kell említeni azt is, milyen fontos a partner személye a karrier szempontjából „A házastárs támogatásának és személyiségének a kérdezettek szakmai sikerességére gyakorolt hosszú távú hatásait, azaz a crossover jelenség speciális megjelenését Solomon és Jackson (2014) ausztrál paneladatokon elemezte. A szubjektív sikeresség indikátora a munkával való elégedettség, az objektív sikeresség jelzőszáma pedig a jövedelem és az elörelépés volt. Adataik azt mutatták, hogy függetlenül attól, hogy férfi vagy női alanyt vizsgáltak, a házastársak személyisége jelentős hatást gyakorolt a munkahelyi eredményességre" (Nagy 2016: 123). 


\section{TEMATIKUS TANULMÁNYOK - Emberierőforrás-menedzsment napjainkban}

hogy olyanná kellene válniuk, mint egy férfinak" (Acker 1990: 150 idézi Nagy 2017: 64).

Az előítéleteken alapuló „láthatatlan” szegregálódástól meg kell különböztetni a látható, fizikai szegregálódást is, mint egy következő akadályt. Ez alapvetően egy olyan komponens, mely a munkahelyi szervezetekben roppant jelentős szerepet kap a pozíciók újraelosztásában.

Egyes kutatók az úgynevezett humántőke-elméletre alapozzák eme jelenséget, alapja pedig az, hogy a férfiak általában rengeteg időt szánnak szakmai kapcsolataik kiépítésére. Így válik számukra ez a tényező a munka esszenciális részévé. Vizsgálataik rámutattak arra, hogy a nők nem, vagy csak a férfiaknál jóval kevesebb társadalmi tőkét gyűjtenek össze, ezért kevésbé valószínű, hogy vezető pozícióba kerülhetnek (Dreher 2003). Tehát még ma is az „öregfiúk klubjában”, azaz zárt körben dőlnek el a vezetői kinevezések (Nagy 2017).

Hasonló jelenséget ért Carli és Eagly a már említett (IV) társadalmitőke-befektetés alatt. Megállapításuk szerint, bár a nők általában nagyon kevés időt töltenek a kollégáikkal a munkán kívül, ugyanakkor ezek alapvetően olyan sporteseményeken (pl. vadászat, póker, futball vagy egyéb férfifoglalatosságokban) való részvételt jelentenek, melyben a nők nem szívesen vesznek részt, vagy eleve nem is vehetnek részt benne. Holott ezek révén, melyek hivatalosan ugyan nem jelentik a munka szerves részét, bizonyíthatóan olyan társadalmi tőkéhez jutnak a férfiak, amely mégis a munkahelyi előrelépéshez segíti őket (Carli - Eagly 2007). Vagyis kimutatható, hogy sok esetben leginkább a kapcsolati tőke befolyásolja, vagy alakítja ki a vezető posztok újraelosztását, és nem kizárólag a szakmai teljesítmény.

Régóta felismerték azt is, hogy pl. a tudományban általánosan jellemző az a jelenség, mely szerint a kinevezések és a jutalmak egyenlőtlenül oszlanak el a tudósok között. Ez az úgynevezett „Máté-hatás” (Robert Merton által alkotott fogalom), mely a tudósok munkájának aránytalan elismerését eredményezi úgy, hogy nagyobb ismertség esetén a tudósok munkái jobban, míg a kevésbé ismerteké kevésbé vannak jelen a köztudatban. Így végső soron az előnyök olyan személyek között oszlanak el, akik már korábban is elismerést nyertek (Lincoln - Pincus - Koster - Leboy 2012).

Merton ezt az „akinek van, annak adatik, kinek nincs, attól elvétetik” bibliai szövegre építve használta tudományszociológiájában. Ma ezt a fogalmat olyan jelenségek leírására alkalmazzák, amikor az előnyös helyzetű csoportok előnye újratermelődik az intézményrendszerek által, vagyis további előnyökhöz jutnak, míg a hátrányban lévők hátrányai tovább nőnek (Schütter 2003: n. a.). A témára vetítve ez azt jelenti, hogy végül is emiatt a nők azok, akik leginkább kimaradnak a legtöbb elismerésből.

Emellett a nők szakmai erőfeszítései a férfiakhoz képest sokszor leértékelődnek. Míg pl. az amerikai társadalomban tapasztalható nyílt diszkrimináció csökkenő tendenciát mutat, a társadalomtudományi kutatások nagy része mégis kimutatta, hogy 


\section{TEMATIKUS TANULMÁNYOK - Emberierőforrás-menedzsment napjainkban}

a nők által végzett munkát és eredményeket kevésbé tartják fontosnak vagy értékesnek, mint a férfiakét (Lincoln - Pincus - Koster - Leboy 2012: 308).

Ez utóbbi jelenséget legelőször Margaret W. Rossiter azonosította, és nevezte el „Matilda-hatásnak”, amely szerint a nők tudományos munkáját, eredményeit sokszor a férfi kollégáiknak tulajdonítják, vagy teljesen figyelmen kívül hagyják azokat. Ebben az esetben fontos megjegyezni, hogy a kutatások szerint nem csak a férfiaknak vannak nemi előítéleteik. Valójában mind a férfiak, mind a nők kedvezőbben értékelik a férfiakat, mint a nőket, még azonos teljesítményeik esetén is (Lincoln Pincus - Koster - Leboy 2012: 308). ${ }^{12}$

Egyes vizsgálatok emellett azt is kimutatták, hogy a férfiak önértékelése általában magasabb, a nőké pedig alacsonyabb a valós teljesítményüknél, ami sokszor ugyancsak vezethet rosszabb eredményhez, ez a jelenség a „sztereotip fenyegetettség". Steele és Aronson (1995) vizsgálatuk során fekete és fehér bőrű tanulókkal különböző szóbeli tesztet végeztettek, és megállapították, hogy a résztvevők eredményei tipikus fekete-fehér (faji) különbségekből fakadó előítéleteket tükröztek. A vizsgálatukkal igazolták, hogy a faji eltérések mentén tapasztalt teljesítménybeli különbségek leginkább a résztvevők attól való félelme miatt jelentkeztek, hogy megerősíthetik a csoportjukkal kapcsolatos negatív sztereotípiákat. Vagyis ez a fenyegetettség, a sztereotípiák puszta megjelenése is negatívan befolyásolhatja a teljesítményt (Steele - Aronson 1995).

Később Steele és Aronson stereotype threat elméletét más negatívan sztereotipizált társadalmi csoporttal kapcsolatban is megerősítették, beleértve a nők teljesítményét pl. a matematika területén. Mara Cadinu, Anne Maass, Alessandra Rosabianca és Jeff Kiesner 60 nőt két csoportra osztva vizsgáltak meg, miközben megkérték őket, hogy végezzenek el bonyolult matematikai feladatokat. Eredményeik szerint a negatív gondolkodás itt is a teljesítmény csökkenésének egyik lehetséges okaként tételezhető. A „sztereotip fenyegetettség” (stereotype threat) alatt álló női csoportnál kimutatható volt a teljesítmény jelentős csökkenése, melyet alapvetően az úgynevezett „domain-specifikus” gondolkodás eredményezett. Tehát adott csoportról (jelen esetben nőkről) általánosan igaznak vélt tulajdonságokat maguk is interiorizálták (Cadinu - Maass - Rosabianca - Kiesner 2005).

Azonban nemcsak a negatív, de a pozitív nemi kategóriák ugyanúgy benntartják a nőket a hagyományos szerepeikben. Ez a szakirodalom által jóindulatú szexizmusnak nevezett jelenség. Eszerint a nők csak akkor válnak a társadalom szemében elfogadottá, ha a csoportra jellemző feminim tulajdonságokkal bírnak. Ugyanakkor ezek a vezető szerepekre teljességgel alkalmatlan jellemzők (lásd alább a vezetői attitűdöket).

A fentebb felsorolt okok és azok különböző manifesztumai tehát meghatározó módon vannak még mindig jelen és akadályként lépnek elő a nők karrierjének útjá-

${ }^{12}$ Ez a jelenség hasonlít a fent említett Goldberg paradigmához. 


\section{TEMATIKUS TANULMÁNYOK - Emberierőforrás-menedzsment napjainkban}

ban. Mindezen nehézséget tovább erősíti maga a férfi környezet, a „chiling climate” is. Ennek alapja, hogy egy adott munkahelyi szervezetben esetlegesen meglévő férfitöbbség „idegen” légkört hoz létre a bekerülő nők számára, akár a csoportra jellemző tulajdonságokat, akár az ezzel összefüggő, fizikai szegregálódást tekintjük. Gherardi tipológiáját, aki a férfivilágba kerülő nőket („,women travellers in a male world”) pozicionálta, a „vendég”, a „marginális”, a „vakációzó”, a „kígyó a füben”, a „jövevény” és a „betolakodó” jelzők megkülönböztetésével (Nagy 2014 idézi Czibere - Takács 2016).

Sőt, még a nőies területeknek számító bölcsészettudományi karon is tapasztalható volt ez a jelenség. Séllei Nóra bölcsészhallgatókkal folytatott mélyinterjús kutatása során azt tapasztalta, hogy a válaszadók szerint még ez is „lovagias” területnek bizonyul. Interjúalanyai úgy érezték, külön kommunikációs stratégiára van szükségük ahhoz, hogy bele tudjanak illeszkedni ebbe a világba (Séllei 2015).

\section{Akadályok az üvegplafonon túl}

Fentebb azokat az akadályokat vettem sorra, melyek a vezető poszt megszerzése előtt sorakoznak fel. Ugyanakkor azok a nők, akiknek sikerült kikerülni a labirintusból, vagy áttörni az üvegplafont, a vezető posztot betöltve további nehézségekkel kell szembesülniük. Ilyen akadály például az úgynevezett üvegszikla (glass cliff).

Az üvegszikla metafora arra a nehézségre utal, amivel a nőknek akkor kell szembenézniük, amikor vezetői pozíciókat szereznek. Az ilyen vezetői posztok ugyanis gyakran sokkal kockázatosabbak és bizonytalanabbak, mint a férfiaké. Sőt az üvegszikla jelensége szerint a nők kinevezése eleve csak azért volt lehetséges, mert kockázatos vagy bizonytalan volt a szervezet helyzete. Vagyis a nők kinevezése eszerint gyakran egy észlelt jövőbeli bukásra vagy krízisre adott válasz volt (Brückmüller Ryan - Floor - Alexander 2010).

Összességében kijelenthető, hogy ma már a társadalom többsége elismeri a nőket jó szakembereknek, sok posztra ugyanúgy alkalmasnak tartják őket, ahogy a férfiakat, de a legtöbb esetben a vezető szerepekre nem, így a fontos, felelősséggel járó pozíciókat továbbra is a férfiak töltik be.

Ez rezonál a szakértelem és a fegyelem bürokratikus weberi összefüggésével is, mely inkább az egyéni tulajdonságok meglétében látja a jó vezető ideáltípusát. Ugyanakkor, Parsons szerint a szervezetek igazgatásában nem biztos, hogy a legkvalifikáltabbak töltik be az igazgatási és a hivatalnoki pozíciókat. Erre jó példát nyújtanak az egészségügyi intézmények, ahol a legjobb orvosokat inkább a gyógyításban hagyják dolgozni, míg az igazgatást komoly hivatalnokokra bízzák (Czakó 2011).

Így lehetséges az is, hogy pl. a felsőoktatási intézmények vezető pozícióira (rektor), cégvezetőnek vagy akár politikai vezetőnek sem feltétlenül a legjobb szakem- 


\section{TEMATIKUS TANULMÁNYOK - Emberierőforrás-menedzsment napjainkban}

berek kerülnek, hanem a lobbizás, a fent említett szokások, a Máté-hatás, és a többi nemi sztereotípián alapuló kategorizáció mentén többségében férfiak egymás között (old men's club) lesznek megválasztva.

Ezt a tényt tovább igazolja Séllei Nóra kutatása is, aki a Debreceni Egyetem professzornőit vizsgálva állapította meg, hogy egyes szakterületen pl. egyáltalán nincs is nő a vezetők között. „A debreceni egyetemnek vannak olyan »egyetemi« karai (bár ez ma már nem jogi kategória), amelyeken eddig nem került sor professzornő kinevezésére." (Séllei 2015: 267) ${ }^{13}$

Az igazgatáshoz alapvetően a ferfias tulajdonságok szükségesek, a vezetői attitűdök tehát férfias attribútumok. Ráadásul - fogalmazza meg a paradox helyzetet $A$ token helyzet és a meritokrácia illuziója: a kivétel erôsíti a szabályt? című tanulmány, „azok a nők, akik mégis bejutnak a vezető pozíciókba, jellemzően token helyzetben lesznek a magas státusú - "férfias" - területeken, de ez nemhogy csökkentené a velük szembeni előítéleteket, de a sztereotipizálás felerősödése miatt inkább növeli" (Vida Kovács 2017: 145).

Emiatt ráadásul „férfiként” kezdenek el viselkedni, vagyis a férfias tulajdonságok felvételével próbálnak igazodni új szerepeikhez. Így, a token helyzet és a chilling climate együttes hatásaként értelmezhető az asszimiláció mint jelenség általánossá válása a vezető nők körében, ${ }^{14}$ ami viszont visszatetsző eredményhez vezet. Ugyanis a hagyományosan férfias vezetői stílus a nők esetében negatív értékítélettel párosul és kedvezőtlenebb értékelést kapnak. Ez pedig hátrányként lép elő a munkahelyi szervezetekben is.

A szakirodalomban megannyi bináris oppozíción alapuló sztereotip tulajdonságokat gyűjtöttek össze a nemekre vonatkoztatva. Így a női tulajdonságok közé tartozik például a kedves, a vonzó, barátságos, szimpatikus, valamint az érzékeny, szelíd és a kellemes beszédű. Ezzel ellentétben a férfiak elfogadott tulajdonságai közé a különösen agresszív, individualista, ambiciózus, domináns, asszertív, magabiztos, erőteljes, önálló jelzőket párosítják. Utóbbi tulajdonságokat pedig a legtöbb ember a vezetői szereppel azonosítja. Ezért a női vezetők kettős teher alatt találják magukat. Ha a nőkre jellemző tulajdonságokkal bírnak, akkor nem jó vezetők, és kritika alá

${ }^{13}$ „Ilyen az Állam- és Jogtudományi kar (ÁJK), az Informatikai Kar (IK), a Mezőgazdaság-, Élelmiszertudományi és a Környezetgazdálkodási Kar (MÉK) és a Gazdaságtudományi Kar (GTK). Ez azt jelenti, hogy az ezeken a karokon 2015-ben dolgozó 36 professzor között egy nő sincs, és az ezekre a karokra eddig kinevezett összesen 65 professzor között soha nem is volt. [A GTK-n jelenleg van egy professzornö, de ő még a közelmúltban önállóságát elvesztő Közgazdaságtudományi Karon (KTK) kapott kinevezést]” (Séllei 2015: 267).

${ }^{14}$ A női vezetők ugyanis igyekeznek átvenni a pozitívabbnak ítélt társadalmi csoport jellemzőit és a nagyobb tekintélyű identitási csoport tagjaira jellemző tulajdonságokat. Az asszimilációs folyamatok lehetnek akár fizikai, kulturális és társadalmi szerepjellemzők átvételei is (Padilla 2008 idézi Block Koch - Liberman - Merriweather - Roberson 2011: 577). 


\section{TEMATIKUS TANULMÁNYOK - Emberierőforrás-menedzsment napjainkban}

lehet őket vonni, hiszen nem elég erős vezetők. De ha jó menedzserek, férfias jellemzőkkel, akkor ellenszenvesnek tűnnek fel. ${ }^{15}$

„Ugyancsak az identitás részét képezi a nemi szempontból tudatos nyelvhasználat, hiszen a kutatások rámutattak arra, hogy visszatetszést kelt, ha egy nö „túlságosan” magabiztosan és határozottan beszél feladatorientált helyzetekben, mert sérti a nőkkel szemben támasztott elvárásokat (Carli - Eagly 1999). A környezet jobban kedveli a bizonytalanabbul beszéló nőket, akik esetleg segítséget is kérnek valamiben." (Nagy 2017: 62)

\section{Összegzés}

A hátrányos megkülönböztetés mögött, ahogy fentebb is látható volt, a nőkről, a férfiakról és a vezetőkről széles körben jellemző tudatos és tudattalan mentális beidegződések húzódnak. Sok tanulmány megerősítette, hogy az emberek a nőkhöz és a férfiakhoz különböző tulajdonságokat társítanak, amely a munkaerőpiacon a karrierben a férfiaknak kedvez leginkább. A nők karrierje előtt számos akadály sorakozik, melyek mindegyike a tradicionális nemi szerepfelfogásokból és sztereotípiákból erednek.

Ha az eredményeket nézzük, tagadhatatlan, hogy történtek változások minden területen. A tudományos pályán például négy év alatt közel megkétszereződött (17\%) a vezető pozíciót betöltő nők aránya, de a „17\% még mindig csak egyharmada az 50\%-nak, márpedig a PhD-fokozattal rendelkezók fele nő. És hasonlóan aránytalan adatokkal találkozunk akkor is, ha nem a vezetői pozíciót vizsgáljuk, hanem az egyetemi oktatói hierarchia lépcsőfokait." (Séllei 2015: 262)

De mit kell és mit lehet tenni egy ilyen sokrétú problémával?

A gyakran javasolt megoldások között szerepel (Carli - Eagly 2007) pl. antidiszkriminációs jogszabályok érvényre juttatása a szervezetekben. De ne felejtsük el, hogy a jogorvoslat igazából lehetetlen, mert nehéz kimutatni vagy bizonyítani a nemek közötti egyenlőtlenséget, ha a szervezeti struktúrában és a kultúrában betöltött, normákból eredő igazságtalanságokról van szó. Carli és Eagly szerint éppen ezért a leghatékonyabb megoldás az lenne, ha az egyes szervezetek maguk ismernék

\footnotetext{
${ }^{15}$ Kutatók megvizsgálták, hogy milyen tulajdonságok szükségszerűek a sikeres vezetéshez a nők, és milyenek a férfiak esetében. Összegyűjtötték a sikeres vállalatok vezetőire jellemző tulajdonságokat, melyek megerősítették a korábbi TMTM-kutatásokat. Kimutatták, hogy a sztereotipikusan férfiakra jellemző attribútumok a sikeres vállalatok menedzsereinek jellemzőivel azonosíthatók, pl. mint döntő domináns, érzéketlenebb, képes az érzelmektől elválasztani az érzelmeket, gyors felépülés az érzelmi zavaroktól, erőteljes, az érzelmeket elrejti, nagy szüksége van az autonómiára, agresszív. Míg a nők körében sztereotipikus jellegű attribútumok a sikertelenül működő vállalatok vezetőinek sajátjaként írták le a vizsgálatok alapján. Ezek a következők voltak: megértő, intuitív, taktív, figyel mások érzelmeire, hálás, szerény, szimpatikus, rendes, kifinomult, szentimentális, kerüli a vitákat (Ryan - Haslam - Hersby - Bongiorno 2011: 474).
} 


\section{TEMATIKUS TANULMÁNYOK - Emberierőforrás-menedzsment napjainkban}

fel a problémát és tudatosan, még helyben megelőznék vagy orvosolnák azokat (Carli - Eagly 2007).

De, ahogy Nagy Beáta fogalmazott, az a legnagyobb probléma, legyen szó állami vagy szervezeti beavatkozásról, hogy „akiknek módjában és hatalmában lenne a status quo változtatása, azok nem ismerik fel a sztereotípia és az egyenlőtlenség jelenlétét, mivel nem is látják azokat" (Nagy 2017: 63).

Jelen tanulmány célja is többek között az volt, hogy felhívja a figyelmet a probléma létezésére, annak komplexitására, továbbá mindennek napirenden tartására. Hiszen hármas teher van a kettős karriert választó nőkön, „a keresőmunka, az otthoni munka, továbbá a szexista munkahelyi környezettel való megküzdés feladata" (Acker 2009 idézi Nagy 2017: 64).

\section{Irodalom}

Acker, J. (1990): Hierarchies, Jobs, Bodies. A Theory of Gendered Organizations. Gender and Society 4(2) (Jun., 1990), 139-158. http://www.csun.edu/ snk1966/J.\%20Acker\%20Hierarchies,\%20Jobs,\%20Bodies\%20--\%20A\%20 Theory\%20of\%20Gendered\%200rganizations.pdf, letöltés ideje: 2018. 03. 17.

Block, C. J. - Koch, S. M. - Liberman, B. E. - Merriweather, T. J. - Roberson, L. (2011): Contending With Stereotype Threat at Work. A Model of Long-Term Responses 147. The Counseling Psychologist, 39(4): 570-600. https://www.apa.org/education/ce/stereotype-threat.pdf, letöltés ideje: 2018. 05. 05.

Bruckmüller, S. - Ryan, M. K. - Rink, F. - Haslam, S. A. (2010): Beyond the Glass Ceiling. The Glass Cliff and Its Lessons for Organizational Policy. Social Issues and Policy Review, 8(1): 2014. 202-232.

Burgess, D. - Borgida, E. (1999): Who Women are, who women should. Descriptive and Prescriptive Gender Stereotyping in Sex Discrimination Psichology. Public Policy, 999, 5(3): 665-692. https://experts.umn.edu/en/publications/who-women-are-who-women-should-be-descriptive-and-prescriptive-ge, letöltés ideje: 2018. 04. 05.

Cadinu, M. - Maass, A. - Rosabianca, A. - Kiesner, J. (2005): Why do women underperform under stereotype threat? Evidence for the role of negative thinking. Psychological Science, 16(7): 5, 2-578. http://citeseerx.ist.psu.edu/viewdoc/ download?doi= 10.1.1.564.2599\&rep=rep1\&type=pdf, letöltés ideje: 2018.05. 06.

Czakó Á. (2011): Szervezetek és szerveződések a társadalomban. Szervezetszociológiai jegyzetek, Budapest. https://www.tankonyvtar.hu/hu/tartalom/tamop425/ 0010_2A_01_Czako_Agnes_Szervezetek_szervezodesek_a_tarsadalomban-Szervezetszociologiai_jegyzetek/index.html, letöltés ideje: 2018. 05. 05. 


\section{TEMATIKUS TANULMÁNYOK - Emberierőforrás-menedzsment napjainkban}

Czibere I. - Takács I. (2016): Nagy Beáta: Háttérben. Kísérlet egy szervezeti nemi rend feltárására. Újratervezés - a nők és a műszaki tudományok. Debreceni Szemle, 2016/3. 352-356.

Dreher, G. F. (2003): Breaking the glass ceiling: The effects of sex ratios and work-life programs on female leadership at the top. Human Relations, 56(5): 541-562.

Dietz, T. (2005): Frauen und Männer verhalten sich im Bewerbungsgespräch unterschiedlich http://www.uni-passau.de/bereiche/presse/pressemeldungen/meldung/detail/frauen-und-maenner-verhalten-sich-im-bewerbungsgespraech-unterschiedlich/, letöltés ideje: 2018. 05. 01.

Eagly, A. - Carli, L. L. (2007): Women and the Labyrinth of Leadership. Harvard Business Review. https://hbr.org/2007/09/women-and-the-labyrinth-ofleadership, letöltés ideje: 2018.04. 05

Hymowitz, C. - Schellhardt, T. D. (1986): The glass ceiling. Why women can't seem to break the invisible barrier that blocks them from the top jobs. The Wall Street Journal, D1, D4-D5.

Koncz K. (2010): A munkaerőpiac nemek szerinti szegregációjának jelensége és mérése. Statisztikai Szemle, 88(10-11): 1082-1105.

Koncz K. (2011): A munkaerőpiac nemek szerinti szegregációjának jellemzői, mechanizmusa és következményei. Közgazdasági Szemle, LVIII. évf., 2011. január, 74-94.

Koncz K. (2016/a): A női karriertípusok és jellemzőik In: Opus et Educatio 3(1): 30-39.

Koncz K. (2016/b): A mainstream nőpolitika zsákutca?! Magyar Tudomány 2016/4., 461-477. http://www.matud.iif.hu/2016/04/10.htm, utolsó letöltés: 2018. 02. 02.

Kovács M. - Szabó M. (2017): Társadalmi nem és szexizmusok: a nemi hierarchiát igazoló nézetrendszerek elfogadása és elutasítása. In: Kovács M. (szerk.): Társadalmi nemek: elméleti megközelítések és kutatási eredmények, Budapest, ELTE Eötvös Kiadó, 39-57.

Koplányi E. (2018): Nesze nekem anyaság! - Az anyasági hátrány Magyarországon. In: Nagy B. - Géring Zs. - Király G. (szerk.): Dilemmák és stratégiák a család és munka összehangolásában. 304-329.

Kürtösi Zs. (2008): A nők és férfiak társadalmi kapcsolathálózatának eltérései a munkaszervezetben. PhD-értekezés. http://phd.lib.uni-corvinus.hu/352/1/ kurtosi_zsofia.pdf, letöltés ideje: 2018. 05. 09

Lincoln, A. E. - Pincus, S. - Koster, J. - Leboy, P. S. (2012): The Matilda Effect in science: Awards and prizes in the US, 1990s and 2000s, 308-320. 


\section{TEMATIKUS TANULMÁNYOK - Emberierőforrás-menedzsment napjainkban}

Lockwood, N. R. (2004): The Glass Ceiling: Domestic and International Perspectives http://citeseerx.ist.psu.edu/viewdoc/download?doi=10.1.1.470.6766\&rep= rep1\&type=pdf, letöltés ideje: 2018. 05. 01.

Nagy B. (2005): „Nők a vezetésben”. In: Nagy I. - Pongrácz T. - Tóth I. Gy. (szerk.): Szerepváltozások. Jelentés a nők és férfiak helyzetéről, 2005. Budapest, Tárki, Ifjúsági, Családügyi, Szociális és Esélyegyenlőségi Minisztérium, 44-56.

Nagy B. (2016): Ki áll a sikeres nő mögött? socio.hu Társadalomtudományi Szemle, 2016/2. http://socio.hu/uploads/files/2016_2/nagy_beata.pdf, utolsó letöltés: 2018. 05. 01. 117-141.

Nagy B. (2017): Szervezet és nemek. In: Kovács M. (szerk.): Társadalmi nemek: elméleti megközelítések és kutatási eredmények. Budapest, ELTE Eötvös Kiadó, 57-68.

Nagy B. - Primecz H. (2010): Nők és férfiak a szervezetekben - Kísérlet a mítoszok eloszlatására. Vezetéstudomány XLI. évf. 2-17.

Neményi M. (2016): Szülői feladatok és családfenntartás - amikor az anya a fő kenyérkereső. socio.hu Társadalomtudományi Szemle, 2016/2. http://socio.hu/ uploads/files/2016_2/nemenyi.pdf, letöltés ideje: 2018. 01. 01. 243-263.

Pongrácz Tiborné - S. Molnár Edit (2011): Nemi szerepek és a közvélemény változásának kölcsönhatása. https://www.demografia.hu/hu/letoltes/kiadvanyok/ Szerepvaltozasok/192-206Pongracz.pdf, letöltés ideje: 2020.03. 08.

Ryan, M. K. - Haslam S. A. - Hersby, M. D. - Bongiorno, R. (2011): Think crisis-think female. The glass cliff and contextual variation in the think manager-think male stereotype. Journal of Applied Psychology, 96(3): 470-484. http://dx.doi.org/ 10.1037/a0022133, letöltés ideje: 2015. 04. 05.

Séllei N. (2015): Professzornők a Debreceni Egyetemen. Debreceni Szemle 2015/3., 260-278.

Schütter T. (2003): Szerkesztés közben. Új Pedagógiai Szemle, 2003/12. http://folyoiratok.ofi.hu/uj-pedagogiai-szemle/szerkesztes-kozben-35, letöltés ideje: 2018. 11.14.

The Global Gender Gap Report (2017), http://www3.weforum.org/docs/WEF_ GGGR_2017.pdf, letöltés ideje: 2018. 04. 30.11.

The Global Gender Gap Report (2018),

http://www3.weforum.org/docs/WEF_GGGR_2018.pdf, letöltés ideje: 2018. 12. 01.

Simonovits B. - Szeitl B. (2018): Nők és férfiak helyzete - nemzetközi összehasonlításban. https://www.tarki.hu/sites/default/files/trip2018/166-183_simonovits_zeitl_\%20Nok_ferfiak\%20helyzete_javitott_v.pdf, letöltés ideje: 2019.11.14. 


\section{TEMATIKUS TANULMÁNYOK - Emberierőforrás-menedzsment napjainkban}

Vida K.- Kovács M. (2017): A token helyzet és a meritokrácia illúziója: a kivétel erősíti a szabályt? In: Kovács M. (szerk.): Társadalmi nemek: elméleti megközelítések és kutatási eredmények. Budapest, ELTE Eötvös Kiadó, 140-170.

Wingfield, A. H. (2009): Racializing the Glass Escalator-Reconsidering Men's Experiences with Women's Work. Gender \& Society, 23(1): 5-26.

Williams, C. L. (1992): „The Glass Escalator: Hidden Advantages for Men in the „Female” Professions”. Social Problems, 39(3): 1, August 1992, 253-267. https://doi.org/10.2307/3096961 letöltés ideje: 2018. 05. 05.

Williams, C. L. (2013): The glass escalator, revisited: Gender Inequality in Neoliberal Times. SWS Feminist Lecturer. GENDER \& SOCIETY, 27(5), October, 609-629.

Westerwick - Knobloch, S. - Glynn, C. J. - Huge, M. (2013): The Matilda Effect in Science Communication. An Experiment on Gender Bias in Publication Quality Perceptions and Collaboration Interest. Science Communication, 35(5): 603625. 